\title{
Increasing Obstruction to the Outflow Tract in Fallot's Tetralogy
}

\author{
MERVYN S. GOTSMAN ${ }^{\star}$ \\ From the Children's Hospital, Birmingham
}

It is now well recognized that obstruction to the outflow tract of the right ventricle can increase with age. Infants with a ventricular septal defect in infancy can acquire infundibular obstruction of increasing severity and the obstruction can increase further in patients with Fallot's tetralogy (Gasul, Dillon, and Vrla, 1957a; Gasul et al., 1957b; Lynfield, Gasul, and Luan, 1959; Becu et al., 1961; Engle, Ehlers, and Ito, 1964; Walker et al., 1965; Watson and Lowe, 1965).

There are few reports of serial angiocardiographic studies in these children. In this study we set out to examine 9 of a group of 68 patients with Fallot's tetralogy, who underwent one-stage corrective operations in the United Birmingham Hospitals during a four-year period.

In these 9 patients angiocardiography was performed twice. The results will indicate that in these patients the angiocardiogram showed evidence of increasing outflow tract obstruction.

\section{Patients and Methods}

From a group of 68 consecutive patients who had a one-stage corrective operation for Fallot's tetralogy we selected 9 patients. In each of the 9 angiocardiography was performed twice with an interval of at least one year between the first and subsequent procedure. The clinical state of the patient was assessed at the time of each angiocardiogram and a comparison made.

Venous cine-angiocardiography was performed by injecting contrast medium through a short polythene cannula inserted into a suitable vein in the antecubital fossa and advanced up the arm as far as possible. Selective angiocardiography was undertaken during cardiac catheterization. Photography was performed on $16 \mathrm{~mm}$. cine film using a Paillard Bolex H.16 camera and

Received August 12, 1965.

* Present address: The Cardiac Clinic, Groote Schuur Hospital, Observatory, Cape, South Africa. a Phillips 5 in. or 9 in. image intensifier. The processed film was viewed with a "Specto" analytical projector using a fixed film-screen distance. Cineangiocardiograms were taken in the right anterior oblique position with the patient rotated $30^{\circ}$ from the horizontal plane.

A system of angiocardiographic indices was calculated to measure and assess the size of regions of the outflow tract and pulmonary artery. Magnification factors varied for each patient and cine-angiocardiogram. The position of the image intensifier was varied to produce optimal radiographic results with a minimum object-screen and maximum focal-screen distance compatible with adequate radiological exposure. It was placed as close to the patient as possible, while small infants were placed on a false table top to increase the focal-object distance (Gotsman, 1964). For this reason the diameter of the ascending aorta, $1 \mathrm{~cm}$. above the sinuses of Valsalva, was measured during systole and taken as a standard reference measurement. Each diameter measured during that angiocardiogram was expressed as a percentage of the aortic diameter and this was then called the appropriate index. Thus the MPA index was given by the expression,

MPA index $=\frac{\text { diameter of main pulmonary artery }}{\text { diameter of aorta }} \times 100$.

The following diameters were measured: the diameter between the limbs of the crista supraventricularis at its narrowest point during systole and diastole (cristal index: systole and diastole), the infundibular chamber at its widest point during systole and diastole (infundibular index: systole and diastole) the pulmonary valve ring at its lower margin, the transverse diameter of the main trunk of the pulmonary artery (MPA index) and of the proximal portion of the right pulmonary artery (RPA index). By using this simple technique in an angiocardiogram exposed in a given position, individual magnification factors were erased.

Apart from the size of the individual structures, it was possible to assess approximately the size of the intracardiac shunt by using a concept of angiocardio615 
TABLE I

ALTERATION IN CLINICAL STATUS OF CHILDREN IN TIME INTERVAL BETWEEN TWO ANGIOCARDIOGRAMS

\begin{tabular}{|c|c|c|c|c|c|c|c|c|c|c|}
\hline \multirow[t]{2}{*}{ Initials } & \multicolumn{2}{|c|}{ Age (yr.) } & \multicolumn{2}{|c|}{ Clinical status } & \multirow{2}{*}{$\begin{array}{c}\text { Improvement } \\
\text { in } \\
\text { bronchitis }\end{array}$} & \multirow{2}{*}{$\begin{array}{l}\text { Increase } \\
\text { in } \\
\text { cyanosis }\end{array}$} & \multirow{2}{*}{$\begin{array}{c}\text { Increase } \\
\text { in } \\
\text { hæmoglobin } \\
(\mathrm{g} . / 100 \mathrm{ml} .)\end{array}$} & \multirow{2}{*}{$\begin{array}{l}\text { Reduction } \\
\text { in pulmonary } \\
\text { vascularity } \\
\text { on x-ray }\end{array}$} & \multirow{2}{*}{$\begin{array}{l}\text { Alteration } \\
\text { in } \\
\text { cardiogram }\end{array}$} & \multirow{2}{*}{$\begin{array}{l}\text { Increase in } \\
\text { outflow tract } \\
\text { obstruction } \\
\text { on angio }\end{array}$} \\
\hline & $\begin{array}{c}\text { At } \\
\text { first } \\
\text { angio }\end{array}$ & $\begin{array}{c}\text { At } \\
\text { second } \\
\text { angio }\end{array}$ & $\begin{array}{l}\text { At first } \\
\text { angio }\end{array}$ & $\begin{array}{l}\text { At second } \\
\text { angio }\end{array}$ & & & & & & \\
\hline L.H. & 4 & 11 & $\begin{array}{l}\text { Moderate } \\
\text { tetralogy }\end{array}$ & $\begin{array}{l}\text { Moderate } \\
\text { tetralogy }\end{array}$ & - & + & - & - & - & - \\
\hline C.H. & 3 & 5 & & $\begin{array}{c}\text { Moderate } \\
\text { tetralogy }\end{array}$ & - & - & - & - & - & + \\
\hline R.J. & 5 & 9 & & $\begin{array}{c}\text { Moderate } \\
\text { tetralogy }\end{array}$ & & & - & & & $\begin{array}{l}T \\
+\end{array}$ \\
\hline $\begin{array}{l}\text { A.J. } \\
\text { A.K. }\end{array}$ & $\begin{array}{c}4 \\
11 / 52\end{array}$ & $\begin{array}{l}9 \\
2\end{array}$ & $\begin{array}{l}\text { Severe } \\
\text { tetralogy } \\
\text { VSD }\end{array}$ & $\begin{array}{l}\text { Severe } \\
\text { tetralogy } \\
\text { Moderate }\end{array}$ & - & + & - & - & - & - \\
\hline M.M. & $7 / 12$ & 2 & Moderate & $\begin{array}{c}\text { tetralogy } \\
\text { Very severe }\end{array}$ & & & $8 \cdot 5$ & + & - & + \\
\hline C.S. & 6 & 13 & $\begin{array}{l}\text { tetralogy } \\
\text { Moderate }\end{array}$ & $\begin{array}{l}\text { tetralogy } \\
\text { Severe }\end{array}$ & & & $5 \cdot 6$ & + & - & + \\
\hline T.S. & $5 / 12$ & 2 & $\begin{array}{r}\text { tetralogy } \\
\text { Moderate }\end{array}$ & $\begin{array}{c}\text { tetralogy } \\
\text { Very severe }\end{array}$ & - & + & $1 \cdot 0$ & - & + & + \\
\hline & & & tetralogy & tetralogy & + & + & $4 \cdot 0$ & + & - & - \\
\hline
\end{tabular}

Note: + indicates a change; - indicates no change.

relative optical densities of the angiocardiographic contrast opacification of the pulmonary artery and aorta during the dextrogram phase reflect the proportion of right ventricular output passing to each great vessel,

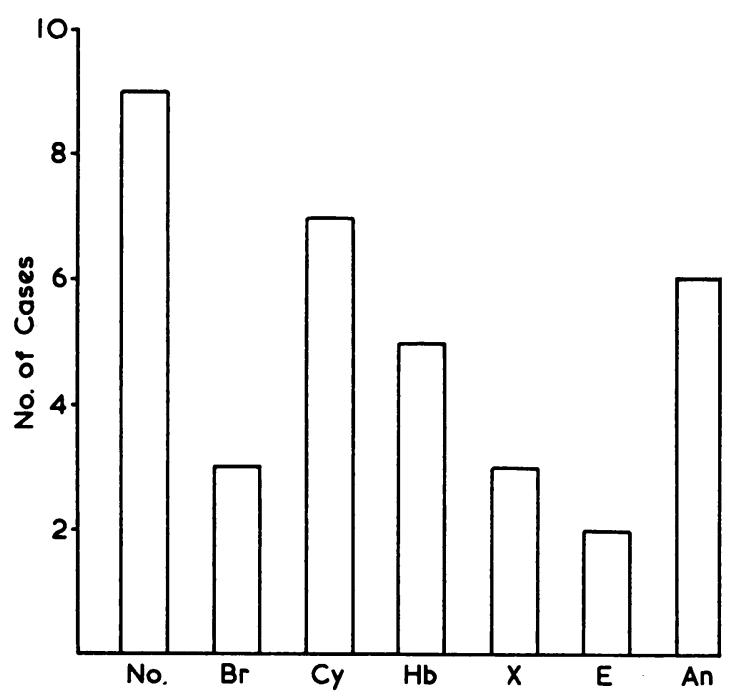

Fig. 1.-Comparison of clinical features in patients who had two angiocardiograms. No. is number of patients studied; $\mathrm{Br}$, indicates infants with bronchitis which improved as the child grew older; $\mathrm{Cy}$, indicates children in whom cyanosis increased; $\mathrm{Hb}$, is for children in whom polycythæmia increased; $X$, is for children in whom there was radiological evidence of decrease in pulmonary vascularity; $E$, is for children in whom the electrocardiogram showed evidence of increase in right ventricular dominance (or reduction in left ventricular dominance); $\mathrm{An}$, is for patients who showed conclusive angiocardiographic evidence of an increase in outflow tract obstruction. though allowance must be made for dilution of the contrast medium entering the aorta by non-opaque left ventricular output. In the same way, a comparison of aortic opacification during the dextrogram and lævogram phases (first to second aortic opacification ratio) is related to pulmonary blood flow. Thus, if there is a large right-to-left shunt and a small pulmonary blood flow, most of the contrast medium passes from the right ventricle to the aorta during the dextrogram phase. There is intense initial opacification of the aorta, and only a little contrast medium enters the pulmonary artery. This is diluted further during its passage through the pulmonary circulation, so that opacification of the left side of the heart is poor, and there is a low density of contrast medium entering the aorta during the lævogram phase. The ratio of first to second opacification density of the aorta is, therefore, high.

\section{RESULTS}

The clinical features at the time of first and second angiocardiographic studies were compared (Table I) and the change is shown in Fig. 1. Three had bronchitis in infancy; this disappeared as the child grew older. In 7 the intensity of cyanosis increased: 5 of these were initially acyanotic. The hæmoglobin concentration increased in 5 with a mean increase of $2.8 \mathrm{~g}$. per $100 \mathrm{ml}$. A reduction in pulmonary vascularity was observed on the chest radiograph in 3 (Fig. 2), and in 2 the cardiogram showed a decrease in left ventricular dominance. In 6 the angiocardiograms indicated an increase in outflow tract obstruction.

The angiocardiographic measurements are shown in Table II. Where the cine-angiocardiogram was unsuitable the measurements were omitted. Three selected indices and the aortic to pulmonary artery 


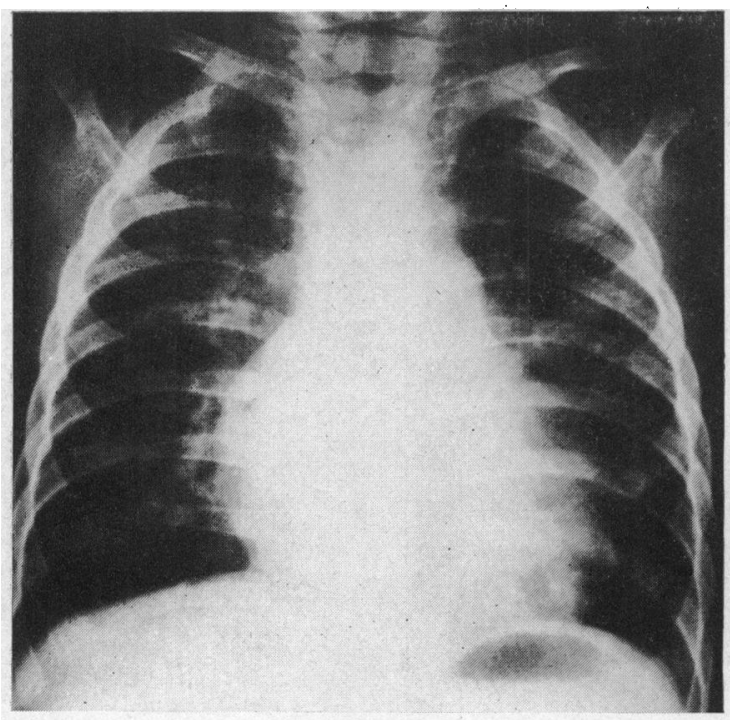

(A)

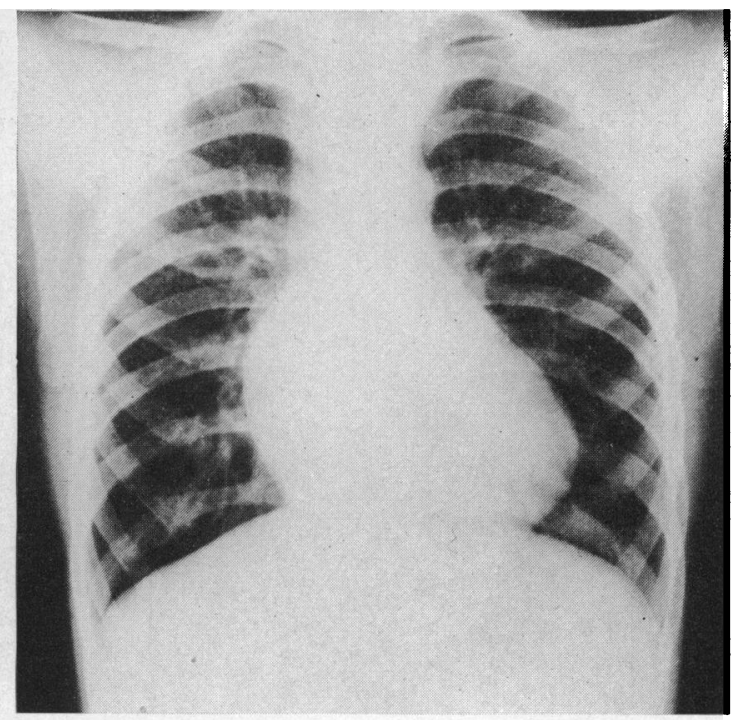

(B)

Fig. 2.-Change in chest radiograph (Patient A.K.). (A) Age 7 months: the child presented in heart failure with the physical signs of a ventricular septal defect and large pulmonary blood flow. The heart was enlarged with a small aorta, prominent pulmonary artery, and pulmonary plethora. (B) Age 3 years: the patient was now slightly cyanosed on exertion. The pulmonary plethora had disappeared, the pulmonary segment was flat, and the aorta more prominent. Angiocardiography confirmed the presence of severe infundibular stenosis, a ventricular septal defect, and a bidirectional shunt. This was repaired at subsequent surgery and the outflow tract required extensive reconstruction with a teflon prosthesis.

and first to second aortic filling density ratios are shown in Fig. 3 and 4 . In 6 of the 9 patients there was an increase in outflow tract obstruction, and in a further 2 there was a reduction in pulmonary blood flow as assessed by relative opacification densities. One patient showed an equivocal change in outflow tract obstruction with an increase in size of the main pulmonary artery.

At operation the children had the typical anatomical defects occurring in Fallot's tetralogy: 4 had a right arching aorta; only 5 had valvar pulmonary stenosis. All had a large ventricular

TABLE II

COMPARISON OF ANGIOCARDIOGRAPHIC INDICES MEASURED AT FIRST AND SECOND CINE-ANGIOCARDIOGRAMS

\begin{tabular}{|c|c|c|c|c|c|c|c|c|c|c|c|}
\hline \multirow[t]{2}{*}{ Initials } & \multirow{2}{*}{$\begin{array}{l}\text { No. of } \\
\text { cine-angio- } \\
\text { cardiogram }\end{array}$} & \multirow{2}{*}{ Route } & \multicolumn{2}{|c|}{ Cristal index } & \multicolumn{2}{|c|}{ Infundibular index } & \multirow{2}{*}{$\begin{array}{l}\text { Ring } \\
\text { index }\end{array}$} & \multirow{2}{*}{$\begin{array}{l}\text { MPA } \\
\text { index }\end{array}$} & \multirow{2}{*}{$\begin{array}{c}\text { RPA } \\
\text { index }\end{array}$} & \multirow{2}{*}{$\begin{array}{l}\text { Ratio of lst to } \\
\text { 2nd aortic } \\
\text { filling density }\end{array}$} & \multirow{2}{*}{$\begin{array}{l}\text { Ratio of aortic } \\
\text { to pulmonary } \\
\text { artery filling } \\
\text { density }\end{array}$} \\
\hline & & & Systole & Diastole & Systole & Diastole & & & & & \\
\hline
\end{tabular}




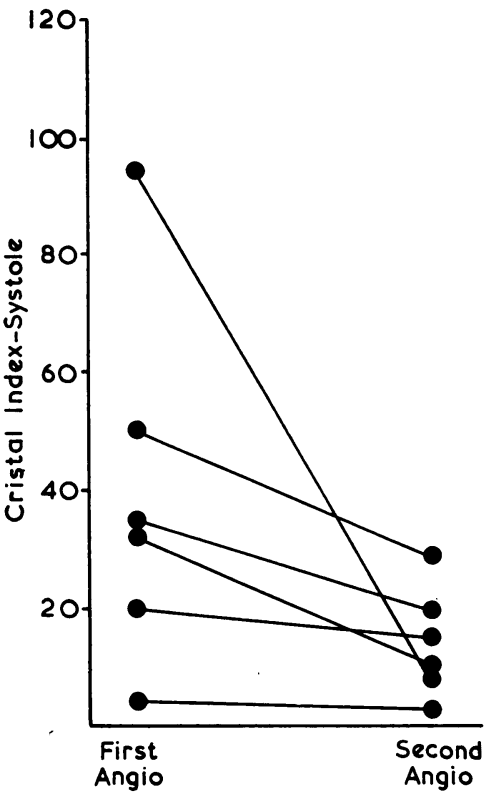

(A)

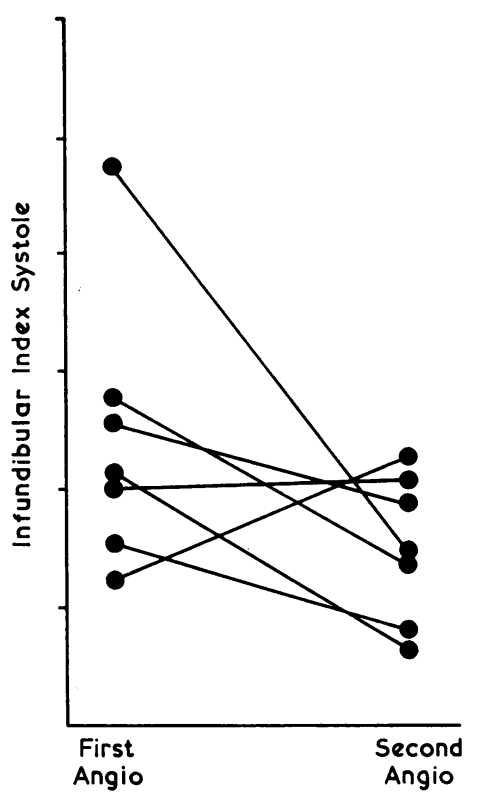

(B)

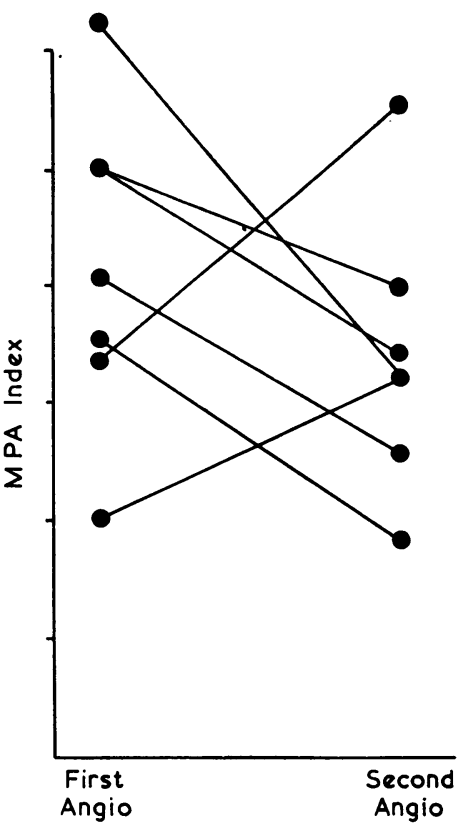

(C)

Fig. 3.-Comparison of angiocardiographic indices as measured at the first and second cine-angiocardiogram. (A) Cristal index during systole: in each patient the cristal index decreased. (B) Infundibular index during systole: in 5 of the patients the size of the outflow tract decreased, indicating a progressive increase in the severity of the outflow tract obstruction. (C) Main pulmonary artery (MPA) index: in 5 patients the relative size of the main pulmonary artery decreased.
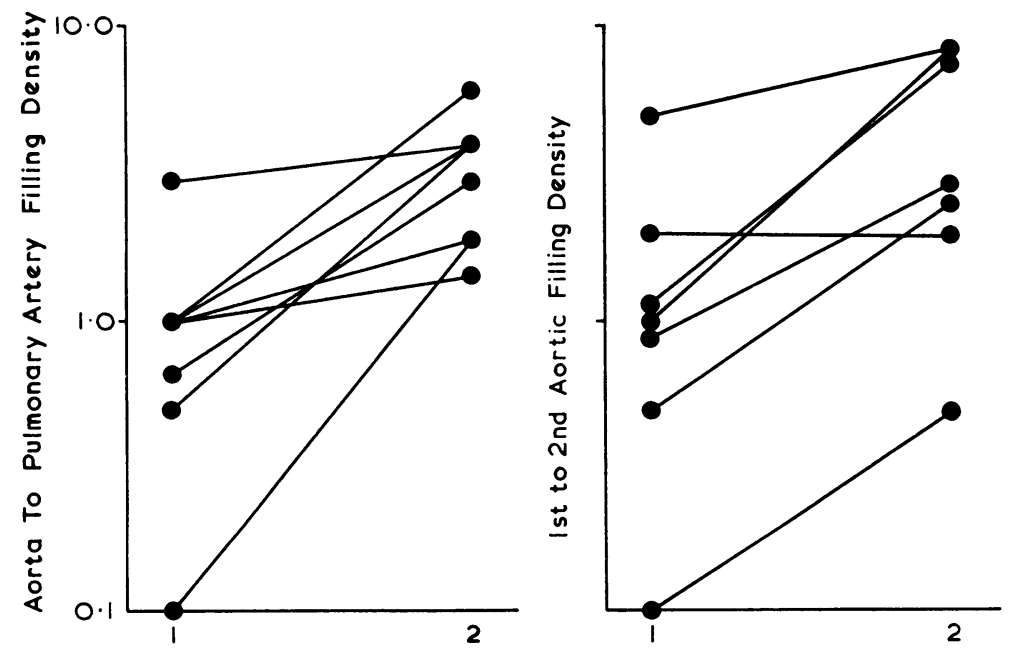

Fig. 4.-Comparison of the aorta-to-pulmonary artery and first-to-second aortic filling (opacification) densities at the time of the first and second cine-angiocardiograms. In all but one of these patients the indices increased, indicating that the right-to-left shunt increased or the left-to-right shunt decreased. 
septal defect, and infundibular obstruction from an abnormal crista supraventricularis.

\section{Discussion}

In interpreting these results one must first assess the validity of the observations. Repeated, sequential clinical observation indicated that cyanosis increased, or the symptoms associated with increased pulmonary blood flow diminished with age. In interpreting the electrocardiographic findings, account was taken of the normal reduction in right ventricular dominance during infancy and childhood. The changes in hæmoglobin concentration were more difficult to interpret. Normal infants are polycythæmic at birth, but this is followed by a physiological anæmia after two to four weeks. The hæmoglobin concentration gradually increases and returns to normal by the second year of life. Rudolph, Nadas, and Borges (1953) showed that children with Fallot's tetralogy have low reserves of iron for an accelerated rate of hæmopoiesis and are unable to maintain their normal polycythæmia. Brinton (1951) also showed that hæmoglobin concentration was not related directly to the arterial oxygen saturation and that the packed cell volume and absolute red cell counts were more valuable. Shephard (1956), too, confirmed that the hæmoglobin increased with age in patients with cyanotic heart disease, though his subjects were over 3 years of age. In another group of patients (unpublished observations) we have observed that infants with cyanotic heart disease show evidence of iron deficiency. Therefore, though we have shown that hæmoglobin concentration increases with age, this may not in fact represent increasing severity of outflow tract obstruction, but an improvement in the relative iron deficiency and anæmia in children who have a large red cell turnover.

Radiological changes present similar difficulties. In adults and older children the chest radiograph is taken under standard conditions during a given phase of respiration. Infants often cry, struggle, or cough at the time of examination, and this alters the appearance of the lung fields. However, in all the infants, serial radiographs were available and the radiological features of pulmonary plethora decreased gradually. Moreover in 4 patients there was simultaneous reduction in the size of the middle segment of the left cardiac border suggesting that the outflow tract and left main pulmonary artery had decreased in size.

The angiocardiographic evidence was more conclusive. Simultaneous electrocardiograms showed that sinus rhythm occurred during venous angiocardiography, but numerous ventricular ectopic beats accompanied a selective right ventricular injection. These ectopic beats increased right ventricular contraction and reduced relaxation during diastole. Moreover a large volume of contrast medium was introduced into the right ventricle during selective angiocardiography, overloading it, and increasing the right-to-left shunt. We have compared angiocardiographic measurements during selective and venous cine-angiocardiography in the same control subjects (Gotsman, 1964), and we have found that though ectopic beats reduce the amplitude of the outflow tract pulsation, severe infundibular spasm does not persist after the second ectopic beat. In the present study, measurements were made during the second and third cardiac cycle after the injection of contrast medium had started, at a time when the effects of the ectopic beats were less conspicuous. Measurements were not recorded unless a suitable sequence was available.

Interpretation of Results. An increase in the severity of the outflow tract obstruction was the most likely explanation for these changes (Gasul et al., 1957a, b; Lynfield et al., 1959; Becu et al., 1961). The angiocardiographic findings showed that the crista supraventricularis was an abnormal anatomical structure contracting late in systole and acting as a dynamic obstruction to right ventricular ejection. In normal subjects observed at angiocardiography the outflow tract relaxed early in systole to become a funnel-shaped channel leading to the pulmonary artery and permitting a high velocity of blood flow. Later in systole the outflow tract contracted, squeezing the final fraction of right ventricular output into the pulmonary circulation and then acting as a support for the pulmonary valve ring and assisting in pulmonary valve closure and competence. The mechanism resembled normal intestinal peristalsis. In patients with Fallot's tetralogy the mechanism was different: the crista supraventricularis contracted earlier in systole. The contractile segment was short and localized to the abnormal crista in milder lesions, but in more severely affected patients this formed a long tubular channel extending as far as the pulmonary valve ring. Our results indicated that this functional obstruction increased with age, increasing the right-to-left shunt through the VSD, reducing pulmonary blood flow and removing the natural stimulus to growth. Consequently the pulmonary artery grew more slowly than the aorta. Taussig et al. (1962) suggested that abnormal areas did not grow at a normal rate. Whether the crista grew more slowly because it has an inherently slower rate of growth, or whether it is more contractile than 
normal, thereby reducing pulmonary blood flow and producing disuse atrophy of the remainder of the region, remains uncertain. The latter explanation may, in part, be true since the size of the pulmonary artery increases after infundibulectomy, indicating a passive response to blood flow (Brock, 1961).

In addition to the slower rate of growth of the outflow tract, we also noted at operation, and we confirmed by biopsy, that the endocardium was thickened and sclerosed. This was further evidence favouring disuse atrophy and sclerosis of the outflow tract. Rodbard (1958) showed that partial narrowing of the lumen of a blood vessel was followed by an ingrowth of connective tissue and the development of a progressive stenosis. He suggested that when the normal distending pressures were eliminated, the intimal layer, freed from the atrophic influences of pressure, was able to grow into the lumen. We observed a similar effect in a patient after a Blalock-Taussig anastomotic operation. She improved after the successful anastomosis but deteriorated later and underwent onestage correction. An angiocardiogram taken before the first operation showed an outflow tract with a satisfactory lumen, but at the time of corrective surgery this was only patent to the probe. After the first operation a smaller fraction of right ventricular output passed through the hypoplastic outflow tract, and since the stimulus to growth was reduced, virtual pulmonary atresia occurred. Fabricius, Hansen, and Lindeneg (1961) have described 3 similar patients.

In 3 of our patients the pulmonary blood flow was above normal in infancy as shown by the conspicuous pulmonary plethora on radiograph. These patients had a normal distending pressure in the outflow tract and a supranormal stimulus for development. The alternative hypotheses are more applicable under these circumstances: the abnormal area grew more slowly while turbulence further disturbed normal growth.

It is well known that the pressure gradient across a stenotic orifice is inversely related to the square of the cross-sectional area (Daugherty, 1937; Gorlin and Gorlin, 1951), and a pressure gradient is not produced unless the cross-sectional area is reduced to one-quarter of the area of the original lumen (Davis, Hyatt, and Howell, 1955; Campbell, 1960). Therefore, with minor degrees of obstruction, the anatomical abnormality may be present without a notable pressure gradient, but once a critical degree of obstruction is reached, a further small increase in obstruction produces a disproportionate increase in gradient. This mild anatomical obstruction will not produce features of outflow tract obstruction until a critical degree of narrowing is reached. The acyanotic children were probably born with a ventricular septal defect and an abnormal crista supraventricularis without hæmodynamic significance in infancy, but with a slower rate of growth more severe obstruction became evident in later childhood. It is also interesting that, in our group of patients, the evidence of pulmonary valve stenosis was low (55\%), suggesting that the ventricular septal defect was the dominant lesion in infancy but that the outflow tract narrowing present as an anatomical abnormality became more severe, producing obstruction of increasing hæmodynamic severity.

Taussig (1960) suggested that polycythæmia, clubbing of the fingers, and the development of a collateral circulation occurred when the physiologically patent ductus arteriosus closed. In the present group of patients, there was no clinical evidence of a patent ductus arteriosus at the time of initial or subsequent examination so that this hypothesis seems unlikely.

\section{SUMMARY}

Angiocardiography was performed twice with an interval of one year in 9 patients who were selected from a group of 68 children who had a one-stage repair operation for Fallot's tetralogy.

In all the patients the clinical picture or angiocardiogram suggested increasing severity of outflow tract obstruction with a reduction in pulmonary blood flow. The possible errors in observation are discussed.

It is suggested that the anatomical abnormality is present at birth but that a slower rate of growth of the abnormal area increases the severity of the obstruction.

I am grateful to Dr. Clifford Parsons, Mr. L. D. Abrams, Mr. K. D. Roberts, and Dr. Roy Astley for encouragement and advice, and to Mrs. J. H. Coull for secretarial assistance.

\section{REFERENCES}

Becu, L., Ikkos, D., Ljungqvist, A., and Rudhe, U. (1961). Evolution of ventricular septal defect and pulmonary stenosis with left to right shunt into classic tetralogy of Fallot. Amer.F. Cardiol., 7, 598.

Brinton, W. D. (1951). Hæmatological changes in cases of congenital cyanotic heart disease which have been submitted to operations designed to improve the circulation to the lungs. Guy's Hosp. Rep., 100, 148.

Brock, R. (1961). The surgical treatment of pulmonary stenosis. Brit. Heart f., 23, 337.

Campbell, M. (1960). Relationship of pressure to valve area in pulmonary stenosis. Brit. Heart $\mathcal{F}_{\text {., }} 22,101$.

Daugherty, R. L. (1937). Hydraulics, 4th ed. McGrawHill, New York. 
Davis, J. O., Hyatt, R. E., and Howell, D. S. (1955). Rightsided congestive failure in dogs, produced by controlled progressive constriction of the pulmonary artery. Circulat. Res., 3, 252.

Engle, M. A., Ehlers, K. H., and Ito, T. (1964). Ventricular septal defect: Progress of past decade. Advance. Pediat., 13, 65.

Fabricius, J., Hansen, P. F., and Lindeneg, O. (1961). Pulmonary atresia developing after a shunt operation for Fallot's tetralogy. Brit. Heart f., 23, 556.

Gasul, B. M., Dillon, R. F., and Vrla, V. (1957a). The natural transformation of ventricular septal defects into ventricular septal defects with pulmonary stenosis and/or into tetralogy of Fallot. Amer. F. Dis. Child., 94, 424.

,,--- , and Hait, G. (1957b). Ventricular septal defects. Their natural transformation into those with infundibular stenosis or into the cyanotic or noncyanotic type of tetralogy of Fallot. $\mathcal{F}$. Amer. med. Ass., $164,847$.

Gorlin, R., and Gorlin, S. G. (1951). Hydraulic formula for calculation of the area of the stenotic mitral valve, other cardiac valves and central circulatory shunts. Amer. Heart F., 41, 1.

Gotsman, M. S. (1964). The relative value of cineangiocardiography in the diagnosis and assessment of children with congenital heart disease. M.D. thesis, University of Cape Town.
Lynfield, J., Gasul, B. M., and Luan, L. L. (1959). Serial physiologic studies of the natural course of 33 infants and children with ventricular septal defects. Circulation, 20, 733.

Rodbard, S. (1958). Physical factors in the progression of stenotic vascular lesions. Circulation, 17, 410.

Rudolph, A. M., Nadas, A. S., and Borges, W. H. (1953). Hematologic adjustments to cyanotic congenital heart disease. Pediatrics, 11, 454.

Shephard, R. J. (1956). The influence of age on the hæmoglobin level in congenital heart disease. Brit. Heart f., 18, 49.

Taussig, H. B. (1960). Congenital Malformations of the Heart, 2nd ed. Harvard University Press, Cambridge, U.S.A.

—, Crawford, H., Pelargonio, S., and Zacharioudakis, S. (1962). Ten to thirteen year follow-up on patients after a Blalock-Taussig operation. Circulation, 25, 630.

Walker, W. J., Garcia-Gonzalez, E., Hall, R. J., Czarnecki, S. W., Franklin, R. B., Das, S. K., and Cheitlin, M. D. (1965). Interventricular septal defect. Circulation, 31, 54.

Watson, H., and Lowe, K. G. (1965). Functional adaptations of the right ventricular outflow tract in congenital heart disease. Brit. Heart f., 27, 408. 